\title{
THE EVALUATION OF CURRICULUM IMPLEMENTATION AT TARBIYAH FACULTY IAIN RADEN FATAH PALEMBANG
}

\author{
Fajri Ismail \\ IAIN Raden Fatah \\ Jl. Prof. KH. Zainal Abidin Fikri Km. 3 1/2, Palembang 30126 \\ difa_firawisata@hotmail.com
}

\begin{abstract}
This research aims to figure out the facts of the objective conditions of the curriculum implementation at Tarbiyah Faculty IAIN Raden Fatah Palembang. The curriculum evaluation used the Evaluation Programme for Innovative Curriculum (EPIC) Model, consisting of three components namely: 1) instruction, 2) institutional, and 3) learning achievement. This research used an evaluative programme to make judgments and decisions of a programme or curriculum. The evaluation results for these three components are: (1) instruction: learning burdens and lecturers' quality are good, but there are still many errors in the presentation, coding, credits of institutional courses, faculty courses, and study program courses, low in task variation, low in the number of hours of meetings, many mistakes in curriculum structure, and low in facilities and infrastructure, (2) institutional: entrance tests for the students of Tarbiyah Faculty IAIN Raden Fatah do not include aptitude tests, lecturers who have magister qualification is good, but low on doctoral qualification, and ratio between lecturers to students is not ideal, (3) learning achievement: students' mastery of teaching skills and attitudes is good, but very low in the mastery of pedagogical skills and teacher education. Recommendations of this research are 1) revise curriculum, 2) use the aptitude test to select new students, 3) increase academic qualifications of lecturers, and 4) revise comprehensive examination system.
\end{abstract}

Keywords: EPIC model, curriculum evaluation, curriculum implementation

In the era of globalization, the current educational paradigm is not just a question of transferring knowledge from faculty to students, but it is about preparing the students to compete in the search for employment. The policies taken by higher education institutions is not only the responsibility of the campus authorities but also all the stakeholders. According to Azra (2012: 52), there are three aspects regarding that condition. The first is the institutional aspect that globalization makes the process of autonomy, devolution, decentralization and privatization of education happen. The second is related to the content of education in which globalization makes knowledge-based society and knowledge-based economy affect the curriculum setting. Last is about globalization characterized by advances in information technology and communication provides the changes in the learning process. Tarbiyah Faculty as part of the State Islamic Institution is facing dynamic challenges in this globalization era in terms of the lack of facilities and lecturers, standardized students' recruitment system and the quality of the graduates. They are still under an issue that remains unresolved homework.

The root of the problem is all about the unclear curriculum used. Azra (2012: 251) states that curriculum structure of Tarbiyah Faculty is dominated by trivial technical problems at the expense of content mastery which is actually more essential in the learning process. In the other words, the curriculum structure contains the materials that are not related to the 
formation of the graduates' competency and sciences education. Janawi (2002: 74) asserts that the imperfection of Tarbiyah Faculty curriculum is due to the reconstruction of topics or course materials which are not integrated and comprehensive. What Azra and Janawi concern about the curriculum is in regard with Curriculum 1995 and Curriculum 2000 that show some weaknesses. At first, the curriculum construction is not integrated, coherent and comprehensive. Second, the structure of current curriculum is based on the interpretation of State Islamic Higher Education that results in the misplacement and composition of courses offered. Third, even though there is any curriculum revision, the courses offered are not different from those in the previous curriculum. The fourth is that the curriculum structure is still dominated by Islamic studies related courses that make the graduates may not be professional teachers.

From the problem above, integrated and comprehensive evaluation of the curriculum is a must for IAIN Raden Fatah Palembang. Based on Hassan (2008: 41), there is a need for curriculum evaluation since it is limited in the context of space and time. Mc. Neil (1996: 201) argues that the urgency of curriculum evaluation is to answer two essential questions; (1) Have the learning process, programs, classes and activities met the expected results? and (2) How can the current curriculum be improved.

This research aims at objectively analyzing the curriculum implementation in three study programs of Tarbiyah Faculty IAIN Raden Fatah Palembang. They are Islamic Education Study Program (PAI), Arabic Education Study Program (PBA) and Elementary School Teacher education (PGMI). This research not only analyzes the structure of curriculum and related documents in the form of syllabus, but also analyzes the supporting components such the quality of lecturers in teaching, facilities, relationship between students and lecturers, and the cognitive, affective and psychomotor domains of learning outcome. Evaluation Program for Innovative Curriculum (EPIC) by Robert L. Hammond is used to evaluate the curriculum. There are three components in the model; learning component, institutional component and learning outcome component.

In accordance with the research focus and limitation, the research problems are as follows: In the learning component, research questions are directed and grouped to four sub-components:

a. Learning Credits

1) How many credits do the students of PAI, PBA and PGMI in Tarbiyah Faculty IAIN Raden Fatah Palembang need to finish their study?

2) Is the coding and number of courses offered the same in every study program of the faculty?

3) Is the learning process conducted by the study programs based on the academic calendar issued by the institution?

4) Is the time allocation of teaching well suited with the learning credits?

5) Is the least teaching frequency the same as the minimum standard in each semester?

6) In the teaching and learning process, how are the tasks given by the lecturers to students? 
7) How is the quality of thesis written by students and consultation process conducted by advisors? Is the thesis examination according to the faculty guidelines?

b. The Structure of Curriculum

1) How are the composition and structure of curriculum related to the vision, mission and graduate' profiles of PAI, PBA and PGMI? Is the structure of curriculum in line with the vision and mission of the faculty and study program?

2) Are the courses offered based on the students' needs and competency?

3) How is the syllabi quality of PAI, PBA and PGMI?

c. Teaching Ability of Lecturers

How is the disciplinary level and teaching ability of Tarbiyah Faculty lecturers?

d. Facilities

How is the quality of facilities of Tarbiyah Faculty? In the institutional component, research questions are directed and grouped to the following sub-components:

a. Students

How is the students' recruitment system of IAIN Raden Fatah Palembang? Is there any teaching test for being the new students of Tarbiyah Faculty?

b. Lectures

1) How is the objective condition of PAI, PBA and PGMI lecturers?

2) Is the ratio of lecturers ideal for the number of PAI, PBA and PGMI students?

3) Why does Tarbiyah Faculty not recruit new lecturers?

In the learning outcome component, research questions are directed and grouped to the following sub-components:

a. Cognitive Domain

How is students' ability in mastering the lessons and related educational insights?

b. Affective Domain

How is the students' attitude?

c. Psychomotor Domain

How is the students' teaching ability?

\section{Evaluation of Curriculum Implementation}

Worthern, Sanders and Fitzpatrick (1987: 5) define evaluation uses inquiry and judgement methods including determining standars for judging quality and deciding whether those standards should be relative or absolute. Print (1993: 1996) states that evaluation is an activity with proper standards of making decision. According to Lovat and Smith (1993: 160), evaluation is the overarching concept which both depends upon measurements and assessment to make a composite judgment or desicion. So, evaluation is a systematic activity that covers measurement and assesment with standards or criteria to make a judgment or decision.

There are two different sides of defining curriculum, narrowly and extencively. Narrowly, Miller and Seller (1985: 3) describes curriculum as a 
subject taught to the students. Zais cited in Giroux and Pinar (1981: 32) describes curriculum as a field of study... (1) range of subject matters with which it is concerned, and (2) the procedures of inquiry and practice that is follows. These opinions describes the curriculum as subjects taught to students.

In contrast, Crow and Crow (1960: 249) defines curriculum includes all the learners experiences in or outside school that included in a program which has been devised to help him develop mentally, physically, emotionally, socially, spritually, and morally. Olivia (1992: 5) adds that curriculum: 1) which is taught in school, 2) a set of subjects, 3) a program of studies, 3) a set of materials, 4) a sequence of courses, 5) a set of performance objectives, 6) everything that goes on within the school, including extra class activities, guidance, and interpersonal relationship, 7) which is taught both inside and outside school. From this definitions, it can be concluded that curriculum is students' activity and experience in teaching and learning process either inside or outside the classroom to help their development.

As a part of curriculum, curriculum evaluation is an overall assessment of the interaction among students, teachers, courses and school environment (Zais, 1976: 378). Olivia (1992: 475) said, it includes evaluation not only of curriculum and instruction but also of the grounds, buildings, administrations, supervision, personnel, transportation, and so on. And Cronbach in Curriculum Design and Development Course Team (1979: 7) defined curriculum evaluation as administrative regulation: judging how good the school system is, how good individual teachers, etc.

Based on theories, curriculum evaluation is not only about classroom activities but also comprehensive assessment process. It is the evaluation of all educational activities such as students, teachers, teaching models and methods, administration and facilities.

One scope of curriculum evaluation is curriculum implementation. Etymologically, implementation is defined an instrument or tool for doing something. (Adams \& Teall, 1965: 472). In the context of curriculum, Beauchamp (1975: 164) curriculum implementation means putting the curriculum to work. Sanjaya (2009: 207) asserts that curriculum implementation is the way to see curriculum as a guideline. Therefore, implementation is basically a teaching and learning process done by teacher and students both inside and outside the classroom.

Ornstein and Hunskin (1998: 293) argue that curriculum implementation contains principal planning focused on three things; human, program and process. Fullan (2001: 47) asserts that the subject of curriculum implementation includes region, society, headmaster, teacher and government. Hamalik (2010: 239 - 244) adds that there are ten elements in the curriculum implementation; 1) curriculum application, 2) introductory language, 3) learning schedule, 4) curriculum activities, 4) educators, 5) facilities, 6) remediation and learning acceleration, 7) guidance and counseling, 8) syllabus arrangement and development, 9) curriculum management, and 10) international school. In brief, curriculum implementation is not only about turning theoretical ideas into practical 
ideas, but also as a program that concerns with supporting components such as students, teachers, headmaster, school environment, facilities, parents, society and government. The result of curriculum evaluation is in the form of decision and consideration on the development of curriculum itself.

\section{Evaluation Program for Innovative Curriculum (EPIC) Model}

In evaluating a curriculum, there are several models that can be used. Each model has its own characteristics. One of them is Evaluation Programme for Innovative Curriculum (EPIC) by Robert L. Hammond. It consists of three components: 1) Learning Component, 2) Institutional Component, and 3) Learning Outcome Component.

In the learning component, there are some sub-components: 1) learning credits, 2) structure of curriculum, 3) teaching ability of lecturers, and 4) facilities. In this model, Hammond (1968: 2) describes learning credits as the duration and order of students' daily and weekly learning activity. In Indonesian higher education, duration is a learning credit, task, practicum and thesis. According to Hammond (1968: 4), structure of curriculum is a content identified as a subject. In EPIC model, the evaluation of content and structure of curriculum is directed to develop the curriculum in order to improve the existing one. For teaching ability of lecturers, Suprahatiningrum (2012: 73) explains that there are five criteria of professional teachers or lecturers. First, they have commitment towards their students and learning process. Second, they deeply understand all the teaching materials and the way to teach. Third, they are responsible for the students' development through varied teaching techniques. Fourth, they are able to think systematically in doing the job. The fifth is that they can be part of society in their profession.

Hammond (1968: 5) defines facilities and payment. Facilities are defined as space and specific equipment used to support the teaching and learning process. On the other hand, payment is defined as a financial need to support the learning activities such as facilities, renovation, and employees' needs in finishing their works. Further, Hammond (1968: 6) describes institutional component as an institutional dimension that evaluates several variables including objective conditions of students, lecturers, professors, family and society.

For learning outcome component, Hammond (1968: 8) describes it by using cognitive, affective and psychomotor domains. Krathwool, Bloom, dan Masia (1971: 6) states that cognitive domain is the ability to review all the material taught by the teachers to the students. Affective domain is learning outcome domain that measures the feeling, act and initiative. Psychomotor domain is the ability to move or act actively.

\section{Evaluation Criteria}

According to the above description, the evaluation criteria in this research can be seen in the following table:

\begin{tabular}{|l|l|l|}
\hline $\begin{array}{l}\text { Compone } \\
\text { nt }\end{array}$ & $\begin{array}{l}\text { Sub- } \\
\text { Component }\end{array}$ & Evaluation criteria \\
\hline I. Learning & $\begin{array}{l}\text { A. Learning } \\
\text { Credit }\end{array}$ & 1 . $\begin{array}{l}\text { The credits to finish the study in S1 with } \\
\text { minimum credits 144 and maximum credits }\end{array}$ \\
\hline
\end{tabular}




\begin{tabular}{|c|c|c|}
\hline $\begin{array}{l}\text { Compone } \\
\text { nt }\end{array}$ & $\begin{array}{l}\text { Sub- } \\
\text { Component }\end{array}$ & Evaluation criteria \\
\hline & & $\begin{array}{l}\text { 160. } \\
\text { 2. The variation in coding and number of courses } \\
\text { offered by the institution and faculty. } \\
\text { 3. Learning process is in line with the institution } \\
\text { and faculty academic calendar. } \\
\text { 4. The suitability of meeting number; maximum } \\
16 \text { times and minimum } 14 \text { times. } \\
\text { 5. The suitability of time allocation for lecturers, } \\
\text { one hour or } 50 \text { minutes for one credit. For } 4 \\
\text { credits, it takes } 200-240 \text { minutes. } \\
\text { 6. The way to give tasks to students is varied and } \\
\text { based on learning objectives. } \\
\text { 7. Good category of students' thesis } \\
\text { 8. The procedure of consultation and thesis } \\
\text { examination must be according to institution } \\
\text { academic handbook: } \\
\text { a. The length of thesis writing and } \\
\text { consultation is } 4-6 \text { month. } \\
\text { Advisor } 1 \text { and advisor } 2 \text { must have } \\
\text { specific tasks. Advisor } 1 \text { improves the } \\
\text { thesis content and theoretical mastery of } \\
\text { students. Advisor } 2 \text { improves the } \\
\text { methodology and writing system. } \\
\text { Thesis examination has to follow the } \\
\text { following procedure: } \\
\text { 1. It is open to the public } \\
\text { 2. Room is designed well and with } \\
\text { academic nuanced } \\
\text { 3. The exam has to be attended by the } \\
\text { two advisors. } \\
\text { 4. It uses power point in presenting the } \\
\text { results of the study. } \\
\text { symbol in the room. }\end{array}$ \\
\hline & $\begin{array}{l}\text { Structure of } \\
\text { Curriculum }\end{array}$ & $\begin{array}{l}\text { 1. The core curriculum based on the vision and } \\
\text { mission as well graduates' profiles is worth for } \\
40 \%-80 \% \text {. For the supporting courses, it is } \\
\text { worth for } 20 \%-40 \% \text { and } 0 \%-30 \% \text {. } \\
\text { 2. There is no mismatch among MPK, MKK, } \\
\text { MKB, MPB and MPB. } \\
\text { 3. Syllabus is well organized with integrated } \\
\text { indicators among standard competency, basic } \\
\text { competency, learning materials, learning } \\
\text { strategies, sources and assessment. }\end{array}$ \\
\hline & $\begin{array}{l}\text { Lecturers' } \\
\text { disciplinary } \\
\text { in teaching }\end{array}$ & $\begin{array}{l}\text { 1. Lecturers do not come later than } 15 \text { minutes } \\
\text { 2. Lecturers have good teaching ability in opening } \\
\text { the activity, explaining, motivating, using } \\
\text { media and closing the activity. The indicator of } \\
\text { lecturers' teaching ability is B. }\end{array}$ \\
\hline & Facilities & $\begin{array}{l}\text { Sufficient facilities to support teaching and } \\
\text { learning activities including appropriate } \\
\text { classrooms, white board, board markers, } \\
\text { praying room, lecturers' rooms and rest rooms. }\end{array}$ \\
\hline $\begin{array}{l}\text { II. } \\
\text { Institution } \\
\text { al }\end{array}$ & Students & $\begin{array}{l}\text { 1. The recruitment process of new students of } \\
\text { Tarbiyah Faculty has to conduct a teaching test } \\
\text { in relation to the professional job of a teacher } \\
\text { and lecturer in Indonesian Constitution. }\end{array}$ \\
\hline
\end{tabular}




\begin{tabular}{|c|c|c|}
\hline $\begin{array}{l}\text { Compone } \\
\text { nt }\end{array}$ & $\begin{array}{l}\text { Sub- } \\
\text { Component }\end{array}$ & Evaluation criteria \\
\hline & & $\begin{array}{l}\text { 2. If the result of teaching test reaches more than } \\
80 \% \text {, it be concluded that the students have a } \\
\text { good chance to be selected. }\end{array}$ \\
\hline & Lecturers & $\begin{array}{l}\text { 1. The standard issued by BSNP for academic } \\
\text { qualification of lecturers shows that the } \\
\text { lecturers that hold master's degree at least } 80 \\
\% \text { and doctoral degree at least } 35 \% \text {. } \\
\text { 2. The standard ration between lecturers and } \\
\text { students based on BSNPP is } 1: 15 \text {. }\end{array}$ \\
\hline \multirow[t]{3}{*}{$\begin{array}{l}\text { III. } \\
\text { Learning } \\
\text { Outcome }\end{array}$} & Cognitive & $\begin{array}{l}\text { The results of the test conducted to the students } \\
\text { in Science Education, Psychology Education, } \\
\text { Education Methods, Education Administration } \\
\text { and Education Evaluation show that they got } \\
35-39 \text { or } C \text { in average. }\end{array}$ \\
\hline & Affective & $\begin{array}{l}\text { The results of the students' affective test } \\
\text { ranging from } 143-180 \text {. }\end{array}$ \\
\hline & $\begin{array}{l}\text { Psychomoto } \\
\mathrm{r}\end{array}$ & $\begin{array}{l}\text { The results of the students' psychomotor test } \\
\text { ranging from } 137-190 \text {. }\end{array}$ \\
\hline
\end{tabular}

\section{METHOD}

The research was conducted at Tarbiyah Faculty IAIN Raden Fatah Palembang from 2013 to 2014 in three study programs. They are Islamic Education Study Program (PAI), Arabic Education Study Program (PBA) and Elementary School Teacher education (PGMI). This research used Evaluation Programme for Innovative Curriculum (EPIC) model by Robert L. Hammond that covers learning component, institutional component and learning outcome component (Hammond, 1968: 2).

Qualitative approach was used in this research by the use of naturalistic characteristic and the evaluator becoming the main research instrument (Patton, 1980: 40). The method used was evaluative research method with the goal to provide consideration and decision towards a program (Lovat and Smith, 1993: 160). The data were collected by interview, questionnaire, observation, document analysis and test. Descriptive statistics and Miles Huberman were used in analyzing the qualitative data. This analysis was done through some stages by data reduction, data display and drawing conclusion.

\section{RESULTS AND DISCUSSION}

\section{Learning Component \\ a. Learning Credits}

\section{1) Number of Credits and Courses}

Competency based curriculum of Tarbiyah Faculty is grouped into five courses: MPK, MKK, MKB, MPB, and MBB. The learning credits of the courses have met the standards set by the government in which the lowest learning credits is at PAI with 144 credits and the highest credits is at PBA with 154 credits. 
The distribution of courses in Tarbiyah Faculty is divided into three groups of courses; INS code for institution courses, TAR code for faculty courses and special code for study program courses. The institution courses are provided to help students learn Islamic competency and as the characteristic of IAN. The faculty and study program courses are the courses provided to help students learn the skills of being a professional teacher.

Twenty five institution courses have different learning objectives from one to the others. The difference can be seen from the following diagram.

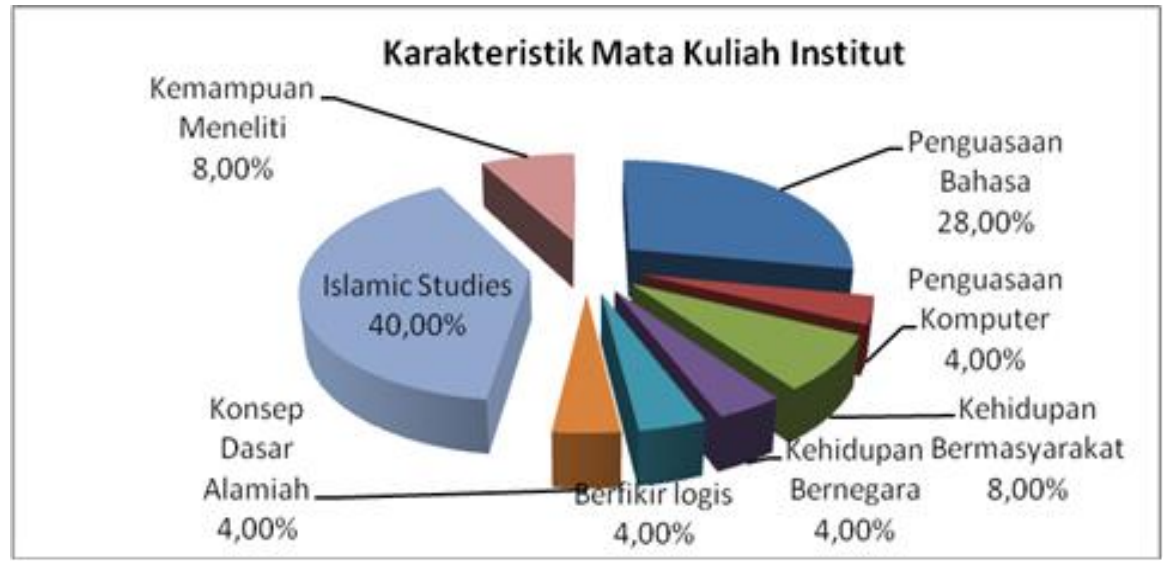

Figure 1. Characteristic of institution courses

Arranged in order, the courses with the learning outcome in the form of Islamic studies competency are 40\%, language mastery (28\%), research skills and social life (8\%), computer literacy, social life, state life, the basic concepts of natural and logical thinking (4\%). This diagram shows that the definition and objective of institution courses as Islamic studies are to help students mastering the basic of Islamic studies.

For faculty courses, it was found that some courses did not describe the graduates' competency as a professional teacher such as MSI, PMDI and Entrepreneurship. The domination of institution courses that actually is not correlated directly with the expected learning outcome has bigger portion so that the graduates' competency of Tarbiyah Faculty to be a professional teacher cannot be achieved.

In Tarbiyah Faculty, there is no standardization of coding and number of credits for all the courses. As a result, there is still misunderstanding in determining the learning credits of PAI, PBI and PGMI.

\section{2) Presentation of Learning Credits in Each Semester}

Most of the students of Tarbiyah Faculty take about $20-24$ learning credits for each semester. This number is quite enough that may probably influence the quality of students' works, learning motivation and achievement. From the students' perspective, the courses taken are just subject matter that must be completed fast without any deep-competencemastery consideration. This is ambivalent with the learning objective in the current curriculum that is based on the mastery of specific competency. 


\section{3) Timeliness of Lecture}

The learning process conducted by Tarbiyah Faculty is usually not on time and does not follow the institution academic calendar. This happens due to the unpreparedness of the faculty in running the SIMAK (online) program because an error in coding the courses so that the scores cannot be input to that program. Moreover, the lack of classrooms makes the study program find difficulties in arranging the rooms for students in the beginning of semester. Then the distribution of teaching schedule for lecturers from the faculty also affects this issue.

\section{4) The Suitability of Time Allocation and Number of Meeting}

Most of the meeting in each semester ranges from 11 to 13 meetings. This quantity of meeting does not meet the number of hours and meetings set by the government which is from 14 to 16 meetings. Lecturers also do not understand the urgency of students' attendance so that they only give them assignment as the substitution of their absence in order to be able to participate in the final semester test.

\section{5) Assignments and Thesis}

In regard to the assignments, the lecturers have given the assignments in the teaching and learning process, but some lecturers only give the assignment in the form of paper writing. Consequently, language mastery of students in translation is ignored. Furthermore, the quality of thesis written by the students is still low because they do not master statistics, research methods and writing techniques. There is also inconsistency between advisors and students when the students consult their thesis revision. The lecturers tend to find the mistakes rather than improve the thesis quality.

In the process of consultation, there is often miscommunication between advisor 1 and advisor 2 that results in the unclear tasks of each advisor. This makes the students confused. Additionally, the thesis examination process seems a formalistic test and not in the academic nuance. The room design also does not meet the aspects set in the faculty guideline handbook that there is no faculty symbol and fewer than three people in charge of the examination.

\section{b. Structure of Curriculum}

The analysis of courses based on the need level in MPK of the three study programs, there are some courses becoming optional because they are not relevant to the graduates' competency. For the courses in MKK, there are also some courses that are not relevant to the graduates' competency. Besides, the analysis of courses based on MKB, there are some courses which are not necessarily needed. For the courses in PGMI, there are eight courses on methods. These courses should be combined into three only. For MPB and MBB, the courses are still needed and relevant to the graduates' competency in each study program.

Vision and mission composed by the three study programs are quite good and represent the graduate's profiles. In contrast, the courses are not parallel with the profiles in each study program. Most of the courses only 
prepare the students to be a teacher without touching the mastery of research methods. This weakness is expressed by Zurqoni (2012: 95) that the formulation of vision, mission and graduates' profiles tend to be seen ideal, but different in its implementation.

Lack of information of the study programs towards the structure of curriculum based competency causes the mistakes in the placement of courses, core and institutional curriculum. Thus, Kepmendiknas No. $045 / \mathrm{U} / 2002$ is not understood by the people in charge of the study programs about the definition and percentage of institutional and core curriculum.

Print (1993: 154) argues that there are two principles to build the structure of curriculum; scope and sequence. Scope is is the depth of the course, and the sequence is a sequence of courses that are presented to the students. Regarding the structure of curriculum of Tarbiyah Faculty in PAI, PBA and PGMI, the curriculum design in each study program has not arranged properly. The indicators are that some courses are not in line with the graduates' competency, the credits are not determined well, and there is inappropriate presentation of courses in each semester.

The quality of syllabus handbook used as a guideline in the three study program does meet the expected standard. It can be seen from the components in the book that are not clear on the relationship among basic competency, indicators, the expected learning outcome and assessment technique that are only in the cognitive domain. Even more, the references are dominated by outdated books. Hence, the information is not up to date.

\section{c. Lecturers' Quality of Teaching}

Generally, the quality of lecturers of PAI, PBA and PGMI in Tarbiyah Faculty is in good category. However, there are some lecturers who are punctual. They tend to change the teaching schedule as they wish. Also, they come later than 15 minutes even 30 minutes. This influences the duration of teaching and learning activities. In addition, there are some lecturers who do not inform the students if they are not able to teach in one occasion so that the students prefer chatting with their classmates, playing outside and going to canteen.

\section{d. Facilities}

The quality of facilities is in bad category. Many components of teh facilities do not meet the standard such as praying room, rest rooms, lecturers' rooms in each study program and the classrooms that do not have air conditioner or fan. As a result, the classrooms become hot and uncomfortable for the lecturers and students in the teaching and learning process.

\section{Institutional Component}

\section{a. Objective Condition of the Students of Tarbiyah Faculty}

Recently, people' belief in educating their children in IAIN Raden Fatah Palembang is increased. It is reported by BAAK IAIN Raden Fatah Palembang that the total number of new students enrolled increases each year. That can be seen from the following graphic. 


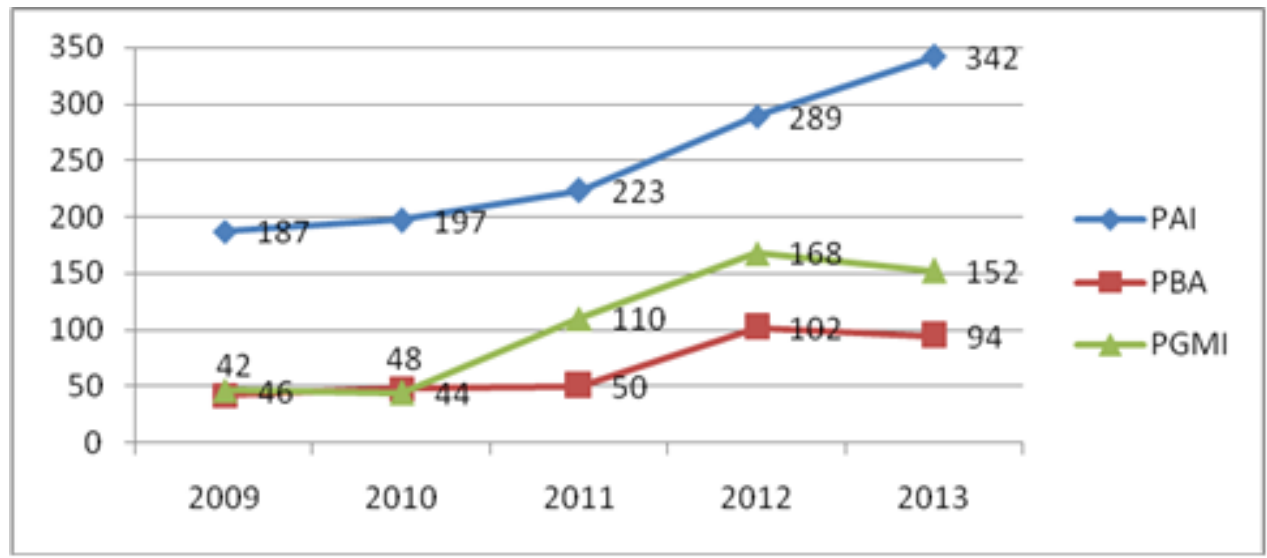

Figure 2. Graphic of New Students Recruitment of PAI, PBA and PGMI (2009 2013)

Nevertheless, the increase on new students studying at the three study programs is in the same token of the increase of facilities and number of lecturers. In the process of recruitment, the institution tends to find the as many students as possible without considering the quality. It also does not involve the parties from the study programs, ignoring the suggestions and needs of the study programs. Furthermore, the entrance test system has not yet been standardized especially teaching test for Tarbiyah Faculty. As a consequence, there are about $23 \%$ students do not deserve to study at Tarbiyah Faculty because they do not have sufficient skills to be a teacher.

\section{b. Objective Condition of Tarbiyah Faculty Lecturers}

Currently, the total number of lecturers of the three study program is 48 lecturers; 23 for PAI, 11 for PBA and 14 for PGMI. Most of the lecturers are still young and productive. Hey can be an asset in the development of the faculty in the future. Even though most of the lecturers have S2 qualification, but the lecturers who holds S3 and professors are not enough, only $16.5 \%$. This number has not yet met the standard of BAN PT which is at least $35 \%$. The growth rate of lecturers can be seen as follows.

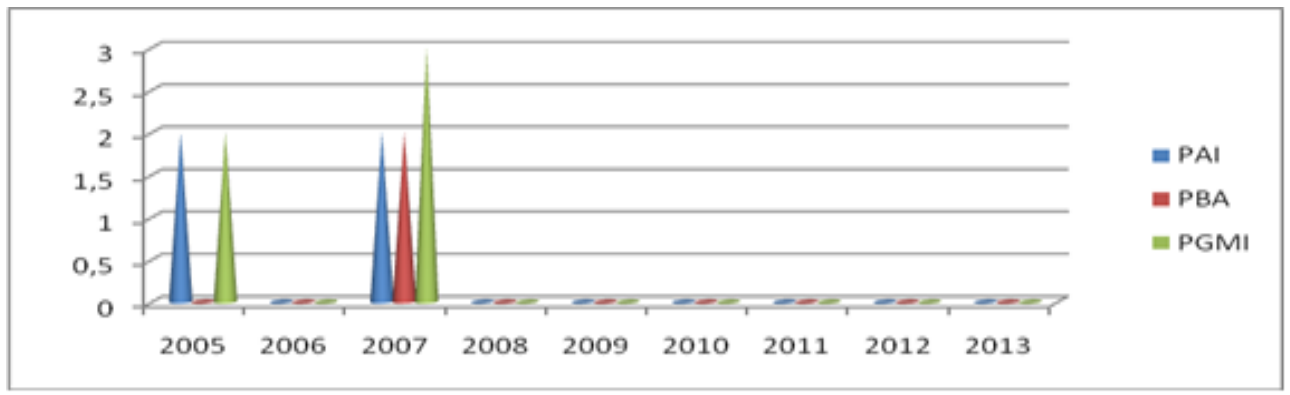

Figure 3. Graphic of Lecturers' Recruitment from 2005 to 2013

The graphic above shows that the rate of lecturers in PAI, PBA and PGMI grows slowly in which the last recruitment done by Tarbiyah Faculty was in 2007. Up to 2013, it means that it has been six years the faculty does 
not recruit new lecturers for the three study programs. Therefore, the ration between lecturers and students are not ideal which is 1:48.

\section{Learning Outcome Component}

The cognitive domain test shows that $48.50 \%$ students of Tarbiyah Faculty in PAI, PBA and PGMI have low pedagogical mastery. From the psychomotor test, the teaching skills of students at Tarbiyah Faculty based on the four lecturers of PAI, PBA and PGMI are in the good category $(56.20 \%)$. From the affective domain, the result of the test shows that the students of PAI, PBA and PGMI of Tarbiyah Faculty are also in the good category $(42.30 \%)$.

The results of the tests above reveal that the students of Tarbiyah faculty have good teaching skills as their professional competency and good affective skill as their social and personal competency. However, the two skills are not supported by good training and education. It can be stated that the alumni of Tarbiyah Faculty of IAN Raden Fatah Palembang have social and personal competency, but lack of pedagogic and professional competency.

The results of the three competency tests of PAI, PBA and PGMI students support the study done by Djuhadi AS (2007: 109 - 209) that the low quality of teachers is from Tarbiyah Faculty. From the four competencies that a teacher must have, professional competency is good, individual and social competency is average, and pedagogic competency is bad.

\section{DISCUSSION}

It is previously mentioned that the heart of teaching and learning process is curriculum. How good the lecturers and facilities are if they are not equipped with good design and structure of curriculum, there will not be effective learning process and qualified graduates. Daulay (2004: 123) states, "the problem of IAIN curriculum should be solved so that there are appropriate courses that may direct to the right indicators for better indoviduals." From this point of view, it is hard to get quality teachers from Tarbiyah Faculty because there are too many institutional and faculty courses that are not correlated directly with the formation of professional teacher competency.

Philosophically, the curriculum of MKK, MPK, MKB, MPB and $\mathrm{MBB}$ is set according to five educational pillars of UNESCO. One of the philosophical objectives is to prepare the future of students well by working on their own competency. By using the concept from Muhaimin (2010: 222) that unites perennial knowledge and acquired knowledge, there is any formulation of curriculum which prepares the students to work in multi sectors.

Indonesian constitutions mention that one of the principles to be a teacher is the teaching skill. Nonetheless, the quality of new students recruited by Tarbiyah Faculty is not promising. Nata (2001: 156) describes the differences between the quality of today's teachers and previous 
teachers, "last time, the teachers are those whose background is teacher education.......Nowadays the input comes to Tarbiyah Faculty is those whose background is senior high school graduates who have minimum or no knowledge in the field of education.

Lack of lecturers in Tarbiyah Faculty is not relevant to the campus autonomy. Sirozi as cited in Sukardi (2008: 122) argues that the development of Islamic Higher Education in the era of decentralization has four strategies. One of them is deregulatory, "in this case, Islamic education should not be attached. The Institutions have to have freedom to create and improve the curriculum, and recruit new lecturers."

From the four competencies that teacher must possess, sosial and personal aspect is in the good category. It is due to the Islamic environment and family factor. However, the pedagogical and professional competencies of IAIN Raden Fatah Palembang students are still low. It can be seen from the results of the tests conducted in some courses offered.

\section{CONCLUSION}

Learning credits of PAI, PBA and PGMI have met the minimum standard set by the government; the lowest is PAI for 144 credits and the highest is PBA for 154 credits. In determining the learning credits, there is misunderstanding whether they belong to institutional, faculty or study program courses since they have different number and codes for the same courses.

Further, the tasks tend to be given to the students in a monotonous way. The mismatch between teaching hours for 4 credits and the number of meetings in each semester usually occurs. The design and structure of curriculum are not coherent with the vision, mission and graduates' profiles due to the lack of understanding from people in charge of study programs. In the same line, the quality of syllabus is still low as the indicators of each component are not integrated. The quality of lecturers is in the good category although there are still some who come late so that their disciplinary needs to be enhanced. Also, the facilities are still insufficient.

In the recruitment process of new students, the focus is only on the quantity without considering the quality. One of the factors is that there is no teaching test during the recruitment. As a result, some students of Tarbiyah Faculty do not have the teaching skills. At the same token, the educational qualification of the lecturers is still low especially for those who have hold doctoral degree or professors, and the ratio between the number of lecturers and students is not adequate.

The results of the tests reveal that the attitude and teaching skills of Tarbiyah Faculty students are in the good category, but the pedagogic skills are still low. It indicates that the attitude and teaching skills are not equipped with good mastery of theory and educational science concept. 


\section{RECOMMENDATION}

Some recommendations from this research are that there is a need to revise the existing curriculum of Tarbiyah Faculty by (1) considering the needs and graduates' competency that has adequate philosophical, psychological and sociological foundations by involving stake holders to achieve ideal curriculum, (2) considering some irrelevant courses to the graduates' competency, (3) dividing the courses on methodology into Research Method 1 with quantitative research design and Research Method 2 with qualitative research design, (4) dividing the teaching methodology courses into conventional methods and learning models, (5) changing the 4 credits into 2 credits,(6) increasing the control of lecturers' teaching time and activities, (7) giving reward and punishment for lecturer, (8) providing research method training periodically for students, (9) revising the syllabus and its components, and (10) revising the curriculum based on Indonesian curriculum qualification format.

In addition, the recruitment process of new students should be improved by having the teaching test. The number of lecturers in each study program should be considered in terms of qualification and expertise. For the learning outcome, the thesis examination process must be comprehensive. There should be standardized scoring system to obtain the same quality of graduates from each study program. Therefore, this examination should be conducted by the institution, not the faculty.

\section{REFERENCES}

Adams, Lewis Mulford, dan Edward N. Teall. A.M. eds., Webster's World University Dictionary. Washington: Publisher Company Inc., 1965.

Azra, Azyumardi. Pendidikan Islam: Tradisi dan Modernisasi di Tengah Tantangan Milenium III. Jakarta: Kencana, 2012.

AS, Djuhadi. "Profil Kompetensi Guru Madrasah Diniyah", Edukasi: Jurnal Penelitian Pendidikan Agama dan Keagamaan, No. 3, Vol. 5, 2007, hh. $109-209$.

Beuchamp, George A. Curriculum Theory. Illinois: The KAGG Press, 1975.

Crow, Lester D., dan Alice Crow. Introduction to Education: Fundamental, Principles, and Modern Practices. New York: American Book Company, 1960.

Daulay, Haidar Putra. Sejarah Pertumbuhan dan Pembaruan Pendidikan Islam di Indonesia. Jakarta: Kencana, 2007.

ᄀ___. Pendidikan Islam dalam Sistem Pendidikan Nasional di Indonesia. Jakarta: Kencana, 2004. 
Fullan, Michael. The New Meaning of Educational Change. New York: Teacher Colledge, 2001.

Giroux, Penna, dan Pinar, eds., Curriculum and Instruction. California: McCutchan, 1975.

Hamalik, Oemar. Dasar-Dasar Pengembangan Kurikulum. Bandung: Remaja Rosdakarya, 2010.

Hammond, Robert L. Evaluation at The Local Level. Arizona: ERIC, 1968 (diakses pada tanggal 15 Juli 2013).

Hassan, S. Hamid. Evaluasi Kurikulum. Bandung: Remaja Rosdakarya, 2012.

Janawi. "Revitalisasi Fakultas Tarbiyah Masa depan: Sebuah Ikhtiar Mengaca Diri”, Jurnal Ta'dib, No. 01, Vol. V, 2002, h. 74.

Krathwool, David R., Benjamin S. Bloom, dan Bertram B. Masia. Taxonomy of Educational Objectives. New York: David Mc.Kay Company, Inc, 1971.

Lovat, Terence J., dan David L. Smith. Curriculum: Action on Reflection. Wentworth Falls: Social Science Press, 1993.

McNeil, John D. Contemporary Curriculum in Thought and Action. Los Angeles: John Wiley and Sons, Inc, 1996.

Miller, John P., dan Wayne Seller. Curriculum Perspective and Practice. New York: Longman, 1985.

Muhaimin, Pengembangan Kurikulum Pendidikan Agama Islam. Jakarta: RajaGrafindo, 2010.

Nata, Abuddin. Paradigma Pendidikan Islam. Jakarta: Grasindo, 2001.

Nizar, Samsul, dan Muhammad Syaifudin. Isu-isu Kontemporer tentang Pendidikan Islam. Jakarta: Kalam Mulia, 2010.

Olivia, Peter F. Developing Curriculum. New York: Harper Collins Publishers, 1992.

Ornstein Allan C., dan Francis P. Hunkins. Curriculum: Foundations, Principles and Issues. Sydney: Allyn and Bacon, 1998.

Patton, Michael. Qualitative Evaluation and Research Methods. London: Sage Publications, 1980.

Sanjaya, Wina. Kurikulum dan Pembelajaran. Jakarta: Kencana, 2009. 
Strauss, Anselim, dan Juliet Corbin. Basics of Qualitative Research. London: Sage Publications, 1990.

Suprahatiningrum, Jamil. Guru Profesional: Pedoman Kinerja, Kualifikasi, dan Kompetensi Guru. Yogyakarta: Ar-Ruzz, 2012.

Sukardi, Ismail, ed., Pendidikan Tinggi Islam dalam Sorotan. Palembang: Tunas Gemilang Press, 2008.

Worthen, Blaine R., James R. Sanders, dan Jody L. Fitzpatrick, Program Evaluation: Alternative Approaches and Practical Guidelines. New York: Longman, 1987. 